\title{
Minority Environmental Activism in Britain: From Brixton to the Lake District
}

\author{
Dorceta E. Taylor
}

Historically, the British environmental movement has been devoid of minority participation, but this is changing very slowly, with the emergence of ethnic minority environmental groups and multiracial environmental alliances. These groups have argued that ethnic minorities have little or no access to public funds earmarked for countryside and wildlife preservation issues. They argue that white environmental organizations do not pay attention to the needs of inner-city minority residents and minority access to the countryside. Increased access, community improvement and beautification projects, environmental education, youth training, community garden projects, and issues of environmental racism are all foci of ethnic minority environmental movements. While some white environmentalists have been supportive of them, others have been uncomfortable with them or even hostile to their existence.

KEY WORDS: Britain; environmental; ethnic minority; black; countryside.

\section{THE BRITISH ENVIRONMENTAL MOVEMENT}

Britain has had a long history of anti-pollution legislation and environmental activism that dates back to a 1273 decree prohibiting the burning of sea coal (this is the world's oldest pollution legislation). The modern British environmental movement grew out of an interest in natural history, specimen collection, artistic representations of nature, and Romanticism. By the mid $1800 \mathrm{~s}$, the damage caused by industrialization, hunting, specimen collection, and the ornamental use of feathers was quite evident. Consequently, the anti-slavery and animal protection activists started focussing

Address correspondence to Dorceta E. Taylor, University of Michigan, School of Natural Resources, 430 East University Avenue, Ann Arbor, MI 48109-1115. 
their efforts on the environment by forming environmental organizations aimed at protecting wildlife, protesting the use of feathers in hats, and increasing access to the countryside. The world's first private environmental group, the Commons, Open Spaces, and Footpaths Preservation Society, was founded in 1865; by the turn of the century, several other environmental groups were established (Vogel, 1986: 31-69; Ashby \& Anderson, 1981; Lowe \& Goyder, 1983; Thomas, 1983; Allen, 1978; Lowe, 1983; McCormick, 1989; 1991).

The earliest environmentalists were elites like John Ruskin, John Stuart Mill, and William Morris. As the movement gained public support, others from the upper and middle classes joined the cause by helping to establish some of the earliest environmental organizations (Vogel, 1986: 31-69). Although the Torrey Canyon oil spill and the publication of Silent Spring by Rachel Carson in 1962 helped to make the environmental movement a modern mass movement, the movement still remained a predominantly white, middle-class, urban-based movement primarily concerned with countryside issues and wildlife preservation (McCormick, 1991; 1989; Vogel, 1986; Lowe et al., 1986; Micklewright; 1987). In 1983, Lowe and Goyder estimated that the environmental movement had between 2.5 and 3 million members ( 4.5 to 5.3 percent of the population), and they predicted that by 1990 the membership would be about 4.5 million members or 8 percent of the population.

Today, the wealthy and the aristocracy still play key roles in the British environmental movement, for example, some environmental organizations are headed by lords, and most environmental issues are discussed in the House of Lords. This is quite significant in a society in which class and region are very important factors. The lower classes are reluctant to support a movement that they perceive to be upper class, urban-based with a strong London bias. The Labour Party, for instance, had a hard time persuading its members to develop an environmental agenda, because the members did not see the environment as a working class issue (Vogel, 1986; McCormick, 1991; 1989; Lowe et al., 1986; Lowe \& Goyder, 1983). An excerpt from UK2000's ${ }^{1}$ Spring 1991 report illustrates the link between the aristocracy and the environment.

\footnotetext{
The resplendent House of Lords Cholmondley Room, with its picturesque terrace overlooking the River Thames, was the venue for a very successful and enjoyable celebration of UK2000 and its work on the 15th of April, 1991. Over a hundred guests, including Leader of the House of Lords, David Waddington and Government Whip, Viscount Astor, as well as many UK2000 sponsors and supporters attended the reception hosted by Lord Norrie on behalf of UK2000.
}

Six of the eight largest, most dominant environmental organizations are old, conservative, preservation-oriented organizations like The National 
Trust, Royal Society for the Protection of Birds, and the Council for the Protection of Rural England. Greenpeace and Friends of the Earth are the only two large organizations that attract a younger, more radical membership. In 1989 the eight largest environmental organizations accounted for 3.2 million of the estimated 4 million members of the environmental movement. The National Trust alone had 1.8 of the 4 million members. It is not surprising, therefore, that much of the discussion in the environmental movement is dominated by concerns for nature and rural preservation (Lowe et al., 1986).

\section{MINORITIES, THE COUNTRYSIDE AND THE MOVEMENT}

Minorities are alienated from the countryside and environmental movement. Two minority activists make this point eloquently. The first writes that

people from black and ethnic minority groups do visit the countryside and enjoy it, but in numbers that are not commensurate with our proportion of the population as a whole. This is partly due to a feeling of alienation, a perception that 'it's not for us', a result of our having been influenced by stereotyping, of not seeing similar people in tourist and other publications, such as Countryside Commission News. (Agyeman, 1990: 3)

Another minority environmentalist, Pollard, writes:

it's as if the black experience is only lived within an urban environment. I thought I liked the LAKE DISTRICT, where I wandered lonely as a Black face in a sea of white. A visit to the countryside is always accompanied by a feeling of unease, dread ... feeling that $I$ don't belong. Walks through leafy glades with a baseball bat by my side. . The owners of these fields these sheep and trees want me OFF their GREEN AND PLEASANT LAND...NO TRESPASS, they want me DEAD...A slow death through eyes that slide away from me. (Pollard, 1989: 41-46)

Pollard, a photographer, explains her feelings about the Lake District to a journalist:

I grew up on Wordworth's poetry - 'Daffodils' was my father's favorite poem ... It was the same with the pre-Raphaelites, whom I also used to like for their romantic vision of England and Englishness - like Wordsworth, they went out into the countryside because it freed them to write. But when I went to the Lakes myself, I found I kind of wanted to hide behind a bush. (Coster, 1991: 4)

An article in which Pollard's second quote appeared, drew the following response:

Graham Coster's article in favor of engineering a multicultural rural England (June 1) made depressing reading from the moral point of view. Ensuring that black and Asian people are not deliberately kept out of the countryside is a very different aim to that currently being pursued by some in the National Trust and Countryside 
Commission. They appear to be saying that England's Celtic, Anglo-Saxon and Norman heritage can no longer be tolerated in its undiluted form and must therefore be restructured multi-ethnically. This obsessive desire to neutralize expression of native cultural integrity is unacceptable as any other form of discrimination. (Milson, 1991)

Historically, the movement has been devoid of minority participation (Agyeman, 1988; Thomas, 1986), but this is changing very slowly with the emergence of ethnic minority environmental groups and multi-racial environmental alliances. This raises some interesting questions: why do these groups arise now? What are the core issues of their campaigns, and how do these issues compare to the issues that other environmental groups tackle? Where do ethnic minority environmental groups get their resources from, and how does this affect the political posture of their organizations, their goals and strategies? What is the nature of the relationship between ethnic minority environmental organizations and other environmental organizations?

Minorities in other industrialized countries like the United States and Canada are getting involved in environmental issues too. Like other citizens of these countries, minorities become involved in environmental issues when the issues are salient, when the on-going dialogue strikes a resonant chord, when they are included, when their ideas and concerns are heard and respected, and when their survival and well-being is threatened, and when they are interested in the issues. Minorities in Britain are interested in the countryside and other environmental issues, and they want increased access to the countryside and other recreation resources, but this is not apparent from reading the literature disseminated by environmental groups. Although countryside access is one of the dominant issues discussed in the environmental literature, discussions of minority access, concerns and relationship to the countryside are extremely rare. ${ }^{2}$ In addition, government funders of countryside activities have been very slow to ensure that minorities have access to the countryside. In recent years one minority environmental group has made this issue its central focus.

In the United States, major environmental disasters, discovery of environmental health hazards and widespread environmental degradation has stimulated grassroots participation, and the discovery that minorities are exposed to disproportionate amounts of environmental risks and hazards, resulted in a massive increase in minority participation. The toxic threat has not spawned a significant increase in the level of minority environmental activism in Britain. Although Britain has had its share of environmental disasters including the Torrey Canyon oil spill, the illegal dumping of toxic substances in the Midlands, the discovery of barrels of cyanide on a playground, and the killer London fogs (Vogel, 1986; Lowe, 
1975; Richardson, 1977; Johnson, 1973; Kimber, Richardson and Brooks, 1974; Perry, 1981; Times, 1981; Hildyard, 1981; Enloe, 1975; Elsom, 1987; McCormick, 1991; 1989), these occurrences have not triggered the birth of a sustained new grassroots radicalism that could change the movement in profound ways.

There are about 2.6 million minorities ( 5 percent of the population) living in Britain. Most live in London and other industrial centers of the country; many in poor inner-city neighborhoods. For instance, in 1981, 56 percent of all minorities lived in London and the Southeast, 23 percent in the Midlands and 16 percent in the North and Northwest (Anwar, 1986; Smith, 1986; OPCS, 1981). Although it is quite likely that minorities in Britain are exposed to environmental hazards and risks at home and in the work place, there is some discussion of this among minority environmental activists and no discussions among other environmentalists. There is no research that explores the relationship between race, ethnicity and the exposure to environmental risks and hazards, and these are not likely to appear any time soon. ${ }^{3}$ Without actual evidence linking minorities with increased risks of exposure to environmental hazards then the response of minority communities to toxics is likely to be limited (Liverpool Black Caucus, 1986; Anwar, 1986; Smith 1986; Cashmore, 1989; Rex \& Mason, 1986).

\section{RESEARCH DESCRIPTION}

In the summer of 1991 fieldwork was conducted in Britain to answer the questions raised above. The research was also guided by the following objectives:

1. Examine the historical, social, political, and economic forces that help to define the structure and function of minority environmental organizations.

2. Study the relationship between the position that each organization occupies on the spectrum of minority environmental organizations, and the way each relates to (a) mainstream environmental organizations, (b) other ethnic minority environmental organizations, and (c) to minority grassroots constituencies.

3. Identify the differences or tensions between the stated goals and aims of the organizations and the rhetoric of their leadership. That is, how does the difference between goals and rhetoric relate to the day-to-day activities and actual accomplishments of the organizations? 
4. Find out how the political ideology of the leaders influence the organizations.

5. Document what kinds of activities the organizations engage in, and what kinds of strategies are employed to achieve stated goals.

6. Understand what role members play, if any.

7. Find out the extent to which minority environmental groups are influenced by the leading environmental debates in Britain.

8. Discover how much influence ethnic minority environmental groups have on other environmental organizations. Look for changes in the established sectors of the environmental movement in response to the emergence of these new groups.

From the literature review, a contact person was identified in the leading minority environmental organization and a letter introducing the researcher and describing the project was sent to him. The researcher requested permission to study the organization, i.e., interview past and present leaders, collect background information on the organization, and view internal documents. The snowball sampling technique was used to identify key informants: the contact was also asked if he knew of other minority environmental organizations and who the contact persons were. Two additional organizations were identified this way and the process was repeated. Through further correspondence with each organization, tentative interview dates were scheduled, and publicity materials, brochures, flyers, etc. were requested. Once in Britain, all the organizations were again contacted, and interview times finalized. Attempts were made to interview all the past and present leaders of the organizations for the past three years. Such a time line was established because past leaders often knew more about the history and development of the organization than present leaders. If they have already left the organization they felt freer to talk about sensitive issues, and were often still confidants of, and advisors to existing leaders especially if they left the organization on good terms. Leaders, past and present seemed to be able to recall small events in detail for up to about three years. Beyond that time period recall was very limited and quite unreliable.

In addition, copies of constitutions, conference and workshop materials, handouts, membership lists, minutes of meetings, internal correspondence, articles published by members of the organization, statements and press releases, campaign literature, training documents, annual reports, budgets, goals and aims statements, and organizational history were collected for each organization. These materials were used to help formulate interview questions, supplement interviews, and verify interview data. They were also helpful in the analysis of rhetoric, goals, aims, and day-to-day working of the organization. 
For the purposes of this research, leaders were defined as anyone holding office, sitting on steering committees, management committees, the board, or who was a facilitator in the organization. In addition, people identified by the organization as the "most committed" volunteers were also considered as leaders of the organization. Each leader was interviewed for one to two hours. A second shorter, follow-up interview was requested if clarification was needed or if new information was being sought. A general interview schedule was prepared but parts of it were personalized to match each organization and the role the interviewee played in the organization.

Non-minority environmental organizations were also contacted before the researcher arrived in Britain (by using Frisch's 1990 Directory for the Environment). The annual reports, magazines, flyers, newsletters and other publicity materials were requested from over 100 such environmental organizations. In addition non-minority environmental groups were asked if they knew of or collaborated with any minority environmental groups in Britain or if they have any minority members in their organizations. These materials were examined for: (1) articles on racial and cultural diversity in the movement, (2) articles on minority environmental activism, (3) appeals for minorities to apply for jobs in organizations, (4) minorities sitting on the boards of organizations, (5) hiring of minority staff, (6) collaboration with minorities on environmental projects (7) collaboration with minority environmental organizations, (8) work on environmental issues that benefit minority communities, (9) photographs of minorities in publicity materials, (10) publication of articles written by minorities, (11) increase in minority membership, and (12) minority funding.

These indicators were used to represent how non-minority environmental organizations are responding to the challenges coming from minority communities. Interviews were sought with key individuals leading organizations. Information from the interviews and analysis of materials were used to augment the discussion of the relationship between minority environmental organizations and more established organizations. Other insights on response to minorities arose in my direct contact with these non-minority groups. As a minority myself, with some knowledge of environmental issues, I found that simply raising the issue of minority involvement in the environmental movement was bothersome to some of these environmentalists. The first-hand experiences I received, as an African-American female, while collecting data on this project in Britain, indicate a wide range of racial sensitivities. While many white environmentalists and scholars were very helpful, others were rude, unprofessional and blatantly racist. Despite the fact that meetings were scheduled by letter and by telephone, in some instances, the pleasantries ended as soon as I showed up for the interviews. While I sat in receptionists' offices, appointments were mysteriously canceled. Some 
of those who reluctantly granted the interviews were visibly flustered by the topic. On three occasions I was even grilled with a battery of questions, then later told that they suspected I must be a spy, to have come all the way to England to do research. Finally, on one occasion, after introducing myself, I was asked twice what happened to the "professor from the States" who had scheduled the interview, "wasn't she coming?".

\section{PROFILES OF MINORITY ENVIRONMENTAL GROUPS}

Developing an environmental agenda that makes the concerns, feelings, attitudes, ideas, and vision of minorities central will be very challenging because such an agenda will challenge the status quo in governmental circles, environmental circles and in industrial and corporate circles. Although whites and minorities care about being in the countryside, about open space or about halting urban decay, they have very different perspectives on the issues. As one can see from the reaction to Pollard's description of her visit to the countryside, the introduction of a minority perspective into certain issues is sometimes met with resistance, discomfort, denial, and efforts to delegitimate the voice with that new perspective. Minority presence in certain areas is also problematic for some. The resistance to minority presence does not occur only in the rural hinterlands; some object to their presence in certain urban and suburban open spaces too. For example, when the new community outreach project officer of the Lee Valley Regional Park Authority (a minority female) decided to try to encourage minorities living close to the park to use it by having a community celebration day, some white residents reacted with outrage and great concern for the wildife they thought would be harmed. A flyer (which had a picture of a frog narrowly escaping being squashed by a large foot) was circulated. It read,

\footnotetext{
Bored? Come join us on Disturb-A-Habitat Day! at Middlesex Filter Beds Nature Reserve, Sunday 12th May. Mean Activity Card. I had a go at [little boxes were drawn so that one could check which activity one engaged in]: making a noise, trampling vegetation, finding a nest, swatting a butterfly, throwing litter around, picking wild flowers, paddling with my rottweiler, starting a fire, throwing bricks in the water, squashing a frog, frightening birds. If you can tick off all the activity boxes, you could grow up to be a real nature vandal! (Correspondence sent to Lee Valley Regional Park Authority, April 1991).
}

It is in this climate of alienation, hostility, exclusion, and stereotyping that minorities are creating environmental organizations to empower themselves and to articulate an alternative vision of environmental action. These efforts are met with varying degrees of success. In June 1991 twenty minority groups were identified as having environmental issues as the primary or secondary focus of their agenda. ${ }^{4}$ These groups are concerned with access to 
government environmental funds and to the countryside, with environmental education, ecology, food production and economic development, planning and urban renewal, women and the environment, minority exposure to toxics, and volunteering. One of the largest, most established and well known of these groups is the Black Environment Network. ${ }^{5}$ The Black Environment Network (BEN) grew out of a merger between two groups: the Ethnic Minorities Award Scheme and the Black Environment Network. The Ethnic Minorities Award Scheme started in 1987 with funds from the European Year of the Environment. The funds, channeled through National Council for Voluntary Organizations, were intended to provide small grants to ethnic minority groups who wanted to embark on environmental projects (The BEN Report, 1991: 3). It was hoped that the groups given the initial funding would make contacts with mainstream environmental groups and continue their involvement with environmental issues.

The Black Environment Network was founded in September 1988 at a conference held at the University of London. The conference entitled "Ethnic Minorities and the Environment," was sponsored by Friends of the Earth and the London Wildife Trust (Ethnic Minorities and the Environment Conference Report, 1988); there were delegates from Greenpeace, the Green Party, the Countryside Commission and the British Trust for Conservation Volunteers (Townley, 1988). Minority delegates attending this conference decided to form the Black Environment Network work on issues of concern to minority communities, advocate the need for diversity in the environmental movement and to form a support group for minorities employed or involved in the environmental field. By 1989 there was some overlap between the membership and leadership of the Black Environment Network (all minorities) and the steering group of the Ethnic Minorities Award Scheme (whites and minorities), so both groups merged in April 1990 under the name of Black Environment Network (The BEN Report, 1991: 4). The main goals of the Black Environment Network has been to secure funds to help minority communities undertake environmental projects, ensure access to the countryside, and to help mainstream environmentalists become more sensitive to minority concerns.

The other groups have less complicated origins and, in some instances, less grandiose goals than the Black Environment Network. The Caribbean Ecology Forum, also founded in the late 1980s, started as an organization focussed on halting the toxic trade between Guyana and the United States (Caribbean Times, December 1988; February, 1989; Abbott, 1988; Caribbean Ecology Forum press release, 1988; 1989; The Voice, January 1989), and promoting the traditional land rights and human rights of indigenous peoples in the Caribbean (Caribbean Times, 1988: 16; Guyana Human Rights Association fles). After accomplishing their goals in the 
anti-toxic campaign, leaders of the Forum decided to focus on local minority issues. The membership, which had been a mixture of whites and minorities, dwindled to a few minority activists; their activities were then scaled back to a few speaking engagements in local schools. At the time of this research, they were in the process of reorganizing the group; they changed their name to Karibbean Ecology Trust, and were planning to work with minority youths on environmental education projects.

Another newly formed group, the Overstone Project, hopes to combine environmental education with religion, organic food production, economic development and job training. This group is unique among minority environmental groups because it is a partnership between the New Testament Church of God (one of the largest Afro-Caribbean-led churches in Europe) and an African American community development group, the Watts Labor Community Action Committee. The Overstone group has acquired 32 acres of land on the outskirts of Northhampton on which they plan to grow organic vegetables, train inner-city youths and members of other community organizations in the cultivation and propagation of organic vegetables, and develop a distribution system wherein they can supply the ethnic markets in London and Birmingham with produce (at affordable prices). They plan to launch a massive education campaign in Afro-Caribbean communities aimed at increasing awareness of conservation and environmental issues, 'green' products and services and organic food production. They plan to organize trips so that Afro-Caribbean people can visit Overstone Park "in the heart of the English countryside." The longer term goal of this project is to encourage and facilitate black economic development and environmental awareness in Europe (Brown \& Vernon, 1991).

A different group that focuses on organic food production and conservation is the community of Ashram Acres (located in the Birmingham area). Minorities (from Pakistan, India, Bangladesh, Ireland, the Caribbean and Vietnam) are members of a co-operative that rear animals and grow and sell organic vegetables on a site recovered from derelict dumping grounds. Ashram Acres combines urban environmental concerns with food production, health issues and income substitution; there are daily youth education sessions, and weekly periods of time when nonmembers can volunteer in the gardens. Residents of the surrounding community can borrow tools and learn about seed propagation at Ashram. This venture has become the model for people wanting to establish co-op gardens; visitors from all over Britain visit Ashram Acres to study their operation. The Hindu Temple Group, like the Overstone Project, combines religion with conservation work and youth environmental education. The Hindu Temple Group works primarily with children to clear weeds from pathways to allow access to the River Thames, and to lay trails for the visually handicapped. Adults 
have become interested since the children have become so involved in the conservation work of the group. Consequently, the conservation agenda is being expanded to include the adults. The Hindu Temple Group's conservation work is being funded by the British Trust for Conservation Volunteers (Local Action, 1991: 2; Talking Green, 1991: 7).

The Sunrise Project is a group that was recently formed in the Birmingham and Black Country area. Members of this group were former affiliates of the Black Environment Network but decided to become an independent entity after disagreements arose between the London headquarters and the then Birmingham and Black Country Forum (Shirley, 1990; Griffin, 1991a; 1991b, Wong, 1991). This group plans to launch environmental education projects, support community-run environmental projects, and hire a community outreach person to work with minority communities. The Chinese Health Resource Center, funded by the Black Environment Network in the 1990-1991 award cycle, campaigns in the Chinese community on green issues. It stresses recycling, and monitors the community's use of local recycling stations.

Other groups that have received funding through the Black Environment Network have also continued to develop and broaden their environmental agenda. These groups are, the Oakland Environmental Carnival Troupe, Envirochange, Kashmir Youth Project, Lambeth Chinese Youth Club, Caribbean Hindu Association, ACCRA, Indian Women's Association, Oasis Children's Venture, Calthorpe Project, and An Viet Foundation. The remaining minority environmental groups like the Association for Black People in Planning focusses on the professional development of minorities and planning issues, while the East London Black Women's Organization and the National Alliance of Women of African Descent focus on women and environmental issues. The African Environment Network and the National Coalition of Black Volunteers have environmental projects as a part of their agenda.

Unlike white environmental groups, minority environmental groups tend to emerge from multi-purpose organizations. Instead of being an organization focussed solely on environmental issues, minority organization focus on religion, health, jobs, training, and the environment among other things. The groups emerge as part of community centers, cooperatives and other social and political institutions. This is particularly true of the newer groups that do not have the money or the personnel to develop an organization focussing only on the environment. The organizations like the Black Environment Network, the Association of Black People in Planning, the Karibbean Ecology Trust, that are solely environmental, are older more established organizations. The multi-purpose organization exists partly out of financial necessity or convenience, but also because minorities are not 
separating the religious sphere from the health, job, or environmental spheres. A similar trend exists in the United States where minority environmental groups, in stark contrast to most of their white counterparts, link housing, jobs, health, and religion with environmental concerns. For minorities these spheres are not unconnected, and cannot be dealt with as independent entities.

\section{CHALLENGES AND STRATEGIES}

The following discussion will analyze the context in which environmental activism occurs and what factors enhance or retard the existence and survival of minority environmental groups. It will also look at the relationship between environmental organizations and the government and how that relationship affects minority environmental organizations. The paper will also discuss how minority organizations posture themselves vis-a-vis other environmental organizations, the government and corporations. Finally, the paper will look at strategies that could enhance the survival and growth of minority environmental organizations. The discussion will be facilitated by case studies of the minority environmental groups discussed above. Most of the discussion will focus on the Black Environment Network, but discussions of the other groups will be used to augment the analysis.

There are several major factors affecting the emergence, operation and survival of minority environmental organizations. Each of these factors have important bearing on the structure and function of minority (and other environmental organizations), the relationship between the organization and the government, the relationship with other environmental organizations, the positioning or posture of the organization, and the current and future agenda of the organizations. These factors are: (1) the organizational field, (2) centralized funding sources, (3) non-confrontational style and consensus politics, (4) charitable status, (5) relationship to the grassroots, (6) marginality and powerlessness, (7) size of the organizations, (8) the London bias.

\section{The Organizational Field}

To understand the relationship between ethnic minority environmental organizations and other environmental organizations, we need to know something about the nature of the field minority organizations are operating in (DiMaggio \& Powell, 1983; DiMaggio, 1986; 1983). Such an understanding will help us to analyze the position minority environmental organizations occupy in the field, the way they posture themselves vis-a-vis other 
environmental organizations, and the survival strategies they adopt. One of the major factors organizations have to take into account is the other organizations in their field. This is particularly true of organizations that are competitors, cooperators, or exchange partners (Aldrich, 1979; Pfeffer \& Salancik, 1978; Blau \& Scott, 1962; Evan, 1966; Aldrich \& Marsden, 1988; Perrow, 1986; Scott,1987; Whetten, 1987; Aldrich \& Pfeffer, 1976).

Any minority environmental organization operating in this field has to be clear about whose concerns and needs are foremost on its agenda, and how that choice affects its position and effectiveness in the environmental field and in minority communities. Minority environmental organizations have to weigh the consequences of operating as a mainstream organization, versus operating outside the environmental mainstream; they have to balance the concerns of minorities against those of the preservationists. As mentioned before, the environmental movement is dominated by older, large, conservative, preservation-oriented organizations that set the overall environmental agenda and which influence the flow of conservation funding. Some in these organizations do not see the need for increased minority participation or increased sensitivity towards minority environmental concerns. A summary of the comments made by delegates attending the Ethnic Minorities and the Environment Conference bears this out. Delegates commented that there "was not sufficient emphasis on the environmental context" at the conference and that it "did not allow everyone to understand how the issues under discussion were truly of relevance to them." (Bennett \& Buchanan, 1988).

Most minority environmental organizations are small and are unknown to white environmental groups; some are unknown to other minority environmental activists also. In a phone survey of over a hundred white environmental groups, most had never heard of any minority environmental group, and the few groups who knew of minority groups, knew only of the Black Environment Network and its affiliates. Minority environmental groups, by their mere existence, are perceived to be very political and threatening to some environmentalists. The groups knowing this adopt various coping strategies. For example, the Black Environment Network after lengthy deliberations and a competition to find an agreeable name, decided to keep their name as is. Using "black" in the name is considered to be very political. In interviews with several steering group members of BEN they stressed that it was important for them to choose such a political name, but this name runs up against the image they want to create as a moderate group who can serve as a liaison between mainstream environmental groups and minority communities. As a result their publicity literature stresses the fact that they are not separatist and expands the definition of black to include some white groups. In reference to their name they write, 
The word 'black' is used as a symbolic description of the common experience of all ethnic minority communities, including the less visible white minority communities, such as Polish, the Greek Cypriots or the Irish . . (Local Action, 1991; Community Education Network, 1989).

Other minority environmental organizations have less threatening names, or names that do not link them to the environment or to any racial or ethnic minority group. Consequently, there are no disclaimers following their names. The Karibbean Ecology Trust, which spearheaded a successful direct-action campaign, has recently changed its name and stationery (though the spelling of name hints at radicalism) in an effort to create a new image for the organization.

\section{Centralized Funding Sources}

Centralized funding sources affect the agenda of organizations too. Many environmental groups can and do get funding from government sources, quasi-nongovernmental organizations (quangos) and from private sources. Minority environmental organizations (BEN foremost among them) compete for these same funds also. In short most environmental groups seeking funding turn to the same sources. Not only does this encourage isomorphism (DiMaggio \& Powell, 1983; Galaskiewicz, 1985; 1988; Galaskiewicz \& Burt, 1988; Mizruchi, 1988; Hawley, 1968; Hannan \& Freeman, 1977; Meyer \& Rowan, 1977), but it also helps to define the range of activities the groups engage in. This is particularly true of small groups with limited income.

Ethnic minority groups get funds to do what the funders want to fund. Because they do not have the human and economic resources or the community base to do otherwise, they end up only engaging in activities sanctioned by their funders. In addition, they are careful not to engage in any activities that their funders might deem inappropriate. The Black Environment Network, for instance, is subject to funding oversight at several levels. Their funding is channelled through a charity, the National Council for Voluntary Organizations, which monitors their operation. In addition, funders (even other environmental organizations) have a hand in the running of the organization. All the white steering group members of $B E N$ have past or present connections to organizations that have funded or collaborated with BEN. Steering group members are quick to deny that this is a form of oversight, but one recently-appointed board member said that his organization, UK2000 (a consortium of six powerful environmental groups), funds BEN and that he was asked to monitor the project. The consortium actually developed criteria for funding over and above the criteria that BEN operated with in the past. The Black Environment Network used to obtain 
money from a funder and make final decisions on what projects to support, but the consortium had changed the relationship: BEN now makes recommendations to a contact in the consortium (in this case, the recently-appointed board member) and that contact makes the final decisions on what projects to support (Wong, 1991; Attenborough, 1991).

Funding for the Black Environment Network has increased and has become more diversified over the years. In 1987 they had two funding sources, the European Year of the Environment and the Countryside Commission and by the 1990-1991 fiscal year, BEN received 38 percent of its funds from UK2000, and another 31 percent from the two quasi-nongovernmental organizations, the Nature Conservancy Council (English Nature) and the Countryside Commission. In addition, they received 17 percent of their funds from regional sources, 10 percent from corporate sources, and the remainder from an anonymous donor (Black Environment Network, 1991a; 1991b). Since 1987, they have also had a lot of cash and in-kind support from the National Council for Voluntary Organizations. Although they are receiving money from an increasing number of sources, it is clear they have been heavily reliant on UK2000 and Countryside Commission funding for several years now. Knowing about BEN's funding sources also help us to understand why, for example, funding countryside trips is such a big part of their program. Between 1987 and 1989, 31 percent of BEN's award money went towards funding trips to the countryside (Black Environment Network, 1990b).

The Black Environment Network has tried to diversify its funding base by looking at more private funding sources. They have been able to get some corporate funding, but these too are directed at specific activities that are not radical or critical of industry. For example, in 1991, the funding from their corporate sponsor went towards a symbolic tree-planting project for Environment Week (Wong, 1991). Exploring this avenue of funding has not freed the group from the unpredictability or the restrictions of the funders. In addition to restricting the use of funds, the corporate and environmental sponsors have required that BEN display their logos prominently on its correspondence and publicity literature. These restrictions, advertising criteria, and increasing dependence on corporate funds could be problematic for the organization in the long run.

Funding is one of BEN's biggest concerns; minutes and agenda of the steering group meetings held from March to June, 1991 show that funding was a major part of the discussion at each of these meetings (BEN meeting agenda for March 13, 1991; April 29, 1991; June 25, 1991; June 24, 1991; June 1991). The issue of ethical funding has also become a major concern since BEN has started soliciting and receiving corporate funds; they have been approached by one corporation which they turned down 
for ethical reasons. According to a working paper drafted by Vijay Krishnarayan, a BEN steering group member, BEN would use the criteria set up by the Anti-Apartheid Movement of Britain, Greenpeace, Friends of the Earth, and the Ethical Investment Service to accept or reject funds from corporations (Krishnarayan, 1991; Interview, June 17, 1991; BEN interview with Third World First, 1990).

All the other minority environmental organizations either have funding problems or are subject to funding oversight. The Overstone project has the financial backing and support of the church, Community Service Volunteers, Barclays Bank, City Parochial Foundation, the Prince's Youth Business Trust, and Moulton Agricultural College. Their funding base is broader than that of BEN's, and it has solid support from a church that has over 100 branches in Britain (Brown \& Vemon, 1991). They are one of the only minority environmental groups that is relying so heavily on the support of the minority community.

The environmental activities of the Hindu Temple Group are supported by the Temple and the British Trust for Conservation Volunteers. Their activities, which have been limited to conservation work, will be strictly monitored by the religious group and their conservation funders. The Karibbean Ecology Trust is funded by the contributions donated by the few committed activists currently active in the organization. Because of this severe underfunding they have had to scale back their environmental activities. In the 1990/1991 fiscal year, they applied to the Black Environment Network for funding; they were not funded by BEN, but their application was referred to the Countryside Commission for direct funding (Black Environment Network, 1990). They hope to be in a position to seek more funding from the government and other environmental organizations soon. The Sunrise Project, which used to receive funding from BEN as the Birmingham and Black Country Forum of BEN, has been seeking funds from environmental groups and from local government sources. They are proposing to undertake mainstream environmental education projects because of where they are seeking funding and because they need immediate funds to continue. They are trying to build a strong grassroots base and have been able to tap into some community resources; they might seek more financial support from the community as time goes on (Griffin, 1991).

\section{Non-Confrontational Style and Consensus Politics}

British environmental politics has traditionally been non-confrontational in nature. Environmental groups, the government and industry work out agreements and arrangements without resorting to court battles, embarrassing 
media campaigns, or radical forms of direct action. This lends itself to greater conservatism in the environmental group's approach to conflict resolution. Although the campaign style is becoming more confrontational and high profile, it is not nearly as contentious and litigious as it is in the United States (Lowe et al., 1986; Vogel, 1986; McCormick, 1991; 1989).

So, how are minority environmental groups affected? To enhance its sphere of influence in environmental circles, the Black Environment Network has tried to establish many links with some of these large and powerful organizations; they believe that their style should be non-confrontational. Some excerpts from interviews conducted with leaders of this organization in June and July 1991 demonstrate this point. The director explains how contacts are made:

What we have done is for example we look across the whole of Britain and we sort of think ah that person is open minded and sympathetic, let's set up a private meeting ... if there is an opportunity there, let's go there. So it is not an even approach, it is haphazard but capitalizing on personalities and goodwill.

A steering group member explains the non-confrontational but direct style of the chair:

\begin{abstract}
He has decided that he doesn't want to be confrontational. He doesn't want to go at people, so that is his style to be non-confrontational . . Some people will decide that that's their approach and keep their views quiet and just try to infiltrate behind the scenes and doesn't do that. He doesn't hide what he thinks should happen, but at the same time he doesn't rubbish anybody else or what they are doing. He is positive about it [what others are doing] which is why it works so well.
\end{abstract}

The other minority environmental organizations were not as concerned about being a part of the environmental mainstream. They made no statements in their literature about whether or not they were separatist, or about what styles of activism they would employ. As a matter of fact, most of the other minority organizations do not leave much of a paper trail; they do not have publicity materials, and most of the articles and interviews written or given by minority environmental activists are done by the members of the Black Environment Network. The chair of the Karibbean Ecology Trust did not see the organization in its reorganized form engaging in any high-profile confrontational politics in the immediate future, but did not rule out this possibility if the need arose.

Closely related to the non-confrontational style is the government's use of consensus politics in the making of public policy. In the case of the environment, strict codes and industry-wide standards are not drawn up; instead, standards are worked out with each company according the company's ability to comply with the regulations. Companies are expected to monitor themselves and comply as they are able; the potential embarrassment of being caught violating these norms is supposed to be enough to 
keep companies in line. Few environmental organizations are privy to the discussions between the government and industry. Environmental organizations are invited to participate in policy discussions at the discretion of the government: once an organization has been included in the discussions, the privilege can be withdrawn at any time. Only organizations that are perceived as moderate in their approach to environmental activism are drawn into the inner circle of consensus politicking. Therefore, environmental organizations work to be included in this process, and once they have attained this privileged status they try hard to retain it (Grant, 1978; Lowe et al., 1986; Vogel, 1986; McCormick, 1991; 1989; Lowe \& Goyder, 1983).

When groups are not included in environmental decision making at the early phases of the discussion, and when standards are not universally set and applied, it becomes very difficult to launch a coherent attack on violations or lax standards. By creating the illusion of participation, i.e., inviting a few groups to participate (Grant, 1978), the government has created an atmosphere wherein environmental groups concentrate on being drawn into the inner circle rather than being critical of the process.

None of the minority organizations expressed any ambitions to be a part of this consensus circle in the near future, but by making links with groups that are a part of this circle, by aligning itself with the mainstream, and by designating a steering group member to be responsible for parliamentary lobbying (BEN agenda, June 24, 1991), the Black Environment Network is positioning itself for that possibility sometime in the distant future. For the present, they are privy to the goings-on from second-hand sources (their contacts in the larger environmental groups).

\section{Charitable Status}

Most environmental groups in Britain have charitable status. As a representative of the National Council for Voluntary Organizations (a group working to reform the charity laws) explains, there are many benefits to be derived from charitable status, but there are also strict rules regarding which organizations can qualify as charity and what kinds of activities a registered charity can engage in (see also NCVO's "What is a Charity," 1988; NCVO's Guidance Note 2, 1981; Charity Commissioners' questionnaire, 1990):

there are various benefits to being a charity - tax benefits (you don't pay corporation tax), and you get rate relief (local government tax) . . charities get a 50 percent minimum rebate up to 100 percent rebate . . . there is also tax covenants for people giving money to charity, so companies that give money don't have to 
pay tax on it, and individuals as well ... There is [also] image. If you are a properly registered charity, you are seen as an organization that is basically working in a sensible way . . . It also means that the people who are running it cannot benefit financially ... the whole point is that the charity is a public good.

... the three objectives of charities are: education, the advancement of religion, and the third one is a ... social benefit or public good. More recently the environmental issues have become charitable but the law hasn't changed. You still have to say that [a project or an organization] is environmental and because environment is seen as a public good then you can sneak it [your project proposals] through but you usually have to put something about education as well as increasing public awareness. [In submitting an application for charitable status, you want to be sure] that you have met the educational objective, but the environmental [criteria] has been recognized [only] in the last ten to fifteen years . . . charities are not allowed to campaign; they are not allowed to be political. Well that is a big problem. I mean lots of big charities do lobby ... it is accepted that charities will lobby, but they are not allowed to politically campaign ... it comes down to whether you are trying to change government policy. You are not allowed to directly campaign to change government policy. However, you can lobby your MP and say that we think such and such is needed. You are not allowed to attack government policy and you are not allowed to campaign to change it because that is too political.

Obtaining charitable status and keeping it has a profound effect on the activities of the organization and on what representatives of the organization (speaking on behalf of the organization) can write or speak. During the period of the study, both the Black Environment Network and the Karibbean Ecology Trust were filing for charitable status. Their applications were filed at a time when the charity commissioners were scrutinizing more closely than usual the activities of environmental organizations. Oxfam, in particular, was being reviewed and was in serious danger of losing its charitable status because of its stance on South Africa. Although Oxfam has a charitable trust that does all the relief work and gets all the tax benefits, and an independent political arm that does the campaigning, the charity commissioners were concerned that the political arm was becoming too political; therefore, they threatened to revoke the charity status of the charitable arm.

Both the Black Environment Network and the Karibbean Ecology Trust proposed to do what most environmental organizations do - set up a charitable side to the organization and an independent part that can be political. Both groups were nervous because they were afraid that their organizations would be viewed as being too political already. As a result they tried to stress the educational and public awareness aspects of their organizations (Black Environment Network, 1990a). In 1989, for instance, BEN stated that the organization's aims were "designed to supplement the concerns of enlightened environmentalists in the development of a social justice perspective within the environmental movement," (Community Education Network, 1989), but in its applications to the charity commissioners, such aims were restated as follows (Memorandum of Association, 1991): 
a. to maintain and develop a network of individuals and organizations working for change,

b. to celebrate each other's cultures' contributions and unique interpretation of the environment,

c. to enable the full participation of cultural minorities in the environmental movement

Whereas the Karibbean Ecology Trust engaged in a direct-action environmental justice campaign in their earlier incarnation, the organization that is now applying for charitable status has removed all such possible actions and aims from its proposal. It has also changed its name, stationery, and image to be an environmental education organization. In addition to the statement "thinking globally, acting locally!" the old letter head of the Karibbean Ecology Trust had the following quote from Bob Marley, “. . .when the rain falls, it don't fall on one man's house, remember that!!" These quotes have been replaced on the new letterhead of the Karibbean Ecology Trust by a quote taken from a Tribute to Chico Mendes, "environmental protection, and Social justice, are inseparable."

Both groups badly need charitable status in order to get funding. Funders are very reluctant to give money to organizations that are not registered charities, and since both these organizations have sought to operate with government and private funding, then they need charitable status to get these funds. The Black Environment Network currently gets funding because it is closely linked to a well-established charity. Funds are sent to the charity and it is then funneled to BEN's account. Charitable status would help the organization to eliminate this type of oversight. The Karibbean Ecology Trust operates on a very small budget. If they are to expand their operations and meet their goals of providing environmental education programs for minority youths, then they will need money and staff. They are hoping that charitable status will enhance their fundraising efforts.

Charitable status also forces the organizations to become more formal, i.e., look more like the other organizations in the field (Thompson, 1967; Aiken \& Hage, 1968; Meyer \& Rowan, 1977; Zucker, 1987; DiMaggio \& Powell, 1983; Galaskiewicz, 1988; 1985; Galaskiewicz \& Burt, 1988; Mizruchi, 1988). To be approved, organizations have to have a board; standing committees; a president or chair; a secretary; treasurer; a system of accounting; and some means of legal representation. In an interview with the director of BEN, the following question was asked "is there a leader of this organization? Who is that leader?" The respondent gave the following answer: 
We are very democratic ... What happens is that is the chair and he is also very good at public speaking. I myself my position has changed titles. It is now supposed to be director and I am good at public speaking, so the two of us tend to speak the most at conferences... we are trying to increase the public image of the other members of the steering group...we are really working hard on that ... We are not leadership. We don't believe in leadership at all, because after all the other thing that is very obvious is that the different members of the management committee have very different skills, and [can make different] contribution[s] from [different] direction[s].

Before applying for charity status, both the Black Environment Network and the Karibbean Ecology Trust operated in a very informal way. The Black Environment Network has had to adopt some semblance of a formal structure (a steering committee) to get prior funding, but now for the first time they were assigning committee members to specific positions, and establishing a hierarchy within the organization. The Karibbean Ecology Trust is finding this formalizing process more difficult because they have very few people who are active in the organization. They were in the process of recruiting board members, and assigning positions to the people already in the organization. Other environmental organizations were either too new to go through the charity approval process or were part of other organizations with multiple-purpose agenda.

The quest for charity status has had another interesting effect; it has resulted in the separation of the political nature of the ideas and views individuals express as their own and those they express on behalf of the organization. Views expressed on behalf of the organization are more moderate than those expressed as personal opinion. The Black Environment Network's publicity materials and articles (especially those in publications that reach a predominantly white audience) stress the non-separatist nature of the organization, explain the meaning of "black" in their name, use a broad definition of black, invite whites to join the organization or contribute to it, stress countryside outings, painting environmental murals, doing cultural gardens, incorporating environmental themes in group dance projects, participating in symbolic tree plantings, using window boxes to grow plants, instructions on how to paint a mural or designing a cultural garden, the grants scheme, networking, and environmental awareness (Urban Wildlife, 1990; BEN, 1991a; 1991b; EMAS, 1990/91; EMAS, 1990; EMAS, 1991; Local Action, 1991; BEN/EMAS, 1991a; 1991b; 1990a; 1990b; Shropshire Star, 1990; Wrekin News, 1990; Times Chronicle Series, 1990; Wong \& Agyeman, 1990; South London Press, 1990; Community Education Network, 1989). Two notable exceptions: interview with Third World First, 1990; response to Daily Telegraph article, 1991. Promotional articles published in minority newspapers, etc., are more political in nature than the ones mentioned above (Asian Times, December 11,1990 ), but less political than those expressing individual viewpoints. 
In articles expressing personal opinions, minority activists talk about environmental racism, the imperialist nature of environmental aid, the narrow base of the environmental movement, hostility towards minorities who visit the countryside, toxic exposure in minority communities in Britain and elsewhere, lack of racial and cultural diversity in the environmental movement, lack of employment opportunities for minorities in environmental organizations and government agencies that deal with the environment, pesticide residue on foods, minority alienation from the environmental movement, racism in the environmental movement, lack of public open space for minorities, lack of access to recreational resources for minorities, environmental organizations ignoring the plight of the inner cities and doing work in the Third World, and they link the fervor to eradicate alien species of plants from the British landscape with the a desire to eliminate human aliens or immigrants from Britain (Krishnarayan, 1990/91: 10; Agyeman, 1990a: 22-24; 1990b: 23-25; 1990c; 1990d: 3; 1989a; 1989b: 336-338; 1988a; 1988b; 1988c: 50-51; Agyeman \& Hare, 1988: 39-40). With only a few exceptions (Thorley, 1988), minority activists outside of BEN do not make public statements on the relationship between minorities and the environment. The minority activists from BEN have been alone in raising concerns and issues related to access, diversity, racism, and equality in the environmental movement.

\section{Relationship to the Grassroots}

Most of the minority environmental groups are grassroots operations. They rely on some of the resources of the members, they have strong links to churches, community centers, and other social justice organizations. Several, like the Kashmir Youth Project, the Hindu Temple Group, the Overstone Project, the Karibbean Ecology Trust, and the Oasis Children's Venture focus on educating the youth. The Karibbean Ecology Trust started as a grassroots organization. In their new incarnation, they plan on doing community work. The ideas are being generated by a small group of people with an environmental background, but they plan to keep in close contact with the community, and hopefully have much input from them. The organization will evolve as the participants and organizers see fit. The Overstone Project is rooted in community organization, participation, and advancement. Because they have very strong ties with a church and the community, the community support will encourage this kind linkage for a long time. This group has a great chance of engaging in radical ideas without appearing to be a threat to the system. 
The Black Environment Network is not a grassroots organization: they are not accountable to a membership; the direction and the activities of the organization are not generated from the bottom up; they do not maintain extensive contacts with community groups they might work on projects with; and they do not have extensive links with ethnic minority community social and political organizations. The organization is operated by a small group of very committed activists who form a steering group. They decide which projects they work with, where funding is sought, and what other major decisions concerning the future of the organizations are made. The Black Environment Network does have problems dealing with ideas that are generated from the periphery. They have affiliates (forums) in other parts of the country. One affiliate broke away from the alliance because that affiliate tried to develop some new approaches to working with ethnic minority communities. Those actions caused a rift with the London headquarters. The disagreement was dealt with in an awkward fashion resulting in the breakaway of an innovative and successful affiliate.

\section{Marginality and Powerlessness}

The ethnic minority environmental groups are marginal and have limited power in the environmental field and in the larger society. They are not well known inside and outside the environmental field. Because of the way BEN is funded, leaders spend much of their time pleading their case to other environmentalists, government organizations, and corporations and are at their mercy for funding. This exercise serves to exaggerate their powerlessness and reinforce their vulnerability. ${ }^{6}$ The strategy of trying to move towards the mainstream through connections, and through the kinds of projects they support, has left them even more powerless in some ways; for instance, they haven't run a major environmental campaign as an organization and cannot claim any victories of that sort. They can point to the projects they have funded and say how successful those have been, but they haven't had the experience on running a hands-on campaign. The Black Environment Network has yet to seize an issue and structure a whole campaign around it. The direction that the organization is currently taking (seeking more and more corporate funds) leaves it very little room to embark on such a campaign.

Other groups like the Karibbean Ecology Trust and the Overstone Project hope to establish themselves by tackling one or a few projects that are community based. Having links to a minority-owned and operated institution (Overstone Project, Hindu Temple Group) makes the group more powerful and gives it immediate access to a pre-existing membership pool. 


\section{Size of the Organizations}

Size is a limiting factor on the effectiveness of these minority environmental organizations. They are all very small; BEN has about ten people actively involved in the organization at any given time. The Black Environment Network has one paid staff person, and the number of inactive steering group members is not very large. Although BEN has a mailing list of about 1,000 people who have sought information from the organization, there are no dues-paying members per se. The Karibbean Ecology Trust has four people running the organization, no paid staff and no members. The Hindu Temple Group has one organizer, but has about 30 people participating in its conservation activities. There are about 12 people active in the Sunrise Project; they are seeking funds for a paid staff. Two people are in charge of the Overstone Project, while several people are involved with Ashram Acres. The other organizations tend to have less than 10 active members or leaders. While the Black Environment Network and the Karibbean Ecology Trust haven't established membership criteria yet, and have no plans for membership recruitment campaigns, others like the Hindu Temple Group and Kashmir Youth Project have established membership criteria.

\section{The London Bias}

As mentioned before, 56 percent of the ethnic minorities living in Britain live in the Greater London Area, 23 percent in the Midlands, and 16 percent in the North and Northwest (Anwar, 1986; Smith, 1989; Ballard, 1983; OPCS and Registrar General of Scotland, 1983). This implies that environmental organizations trying to serve these groups should operate outside the boundaries of the London metropolitan area too. Most all the minority environmental groups identified were based in the Greater London Area and some in Birmingham area; the north and western parts of the country is underserved. Being in London has its advantages, but there are disadvantages too. While an organization has access to more than half of the ethnic minority population in the country, it has to make special efforts to keep in touch with minorities in the rest of the country.

\section{DEVELOPING AN ALTERNATIVE ENVIRONMENTAL AGENDA}

Ethnic minority environmental organizations are operating in a field in which there are forces hostile to their existence. They are criticized for 
the names they choose for their organizations, for their desire to have access to the countryside, for their desire to have access to government funds earmarked for environmental activities, for their perspectives on the environment, and for the mere fact that they want to establish minority environmental organizations. This means that they have to pay special attention to the inter-organizational links (for detailed discussions of interorganizational links - micro and macro perspectives - see: Benson, 1975; Galbraith, 1967; Howton, 1969; Gilb, 1966; Birnbaum, 1969; Touraine, 1971; Habermas, 1970; Lefebvre, 1971; Marcuse, 1964; Terreberry, 1968; Turk, 1970; 1973b; Aldrich, 1972; Levine and White, 1960; Cook, 1977; Galaskiewicz and Marsden, 1978) they establish. Links can be established with other minority environmental organizations, with non-minority environmental organizations, with minority organizations not involved in environmental issues, and with non-minority organizations that are not environmental organizations. Because there so few minority environmental organizations currently existing, they have to establish strong links with each other. They need those links so that the ideas they are articulating can be expressed more forcefully. For instance, minority activists connected with the Black Environment Network, and to a lesser extent the Karibbean Ecology Trust, have been raising certain issues about minorities and the environment, but they are alone. None of the other groups are articulating similar ideas, so they are isolated in this respect. They need other groups who share those ideas to come forward and make public statements about them.

Minority environmental groups also need to establish strong links with social and community organizations concerned with social justice issues. In this way they have the force of the membership of those organizations behind them. In addition the organizations have to establish links with other environmental organizations so that they can collaborate on projects, or supplement their funding sources.

The minority organizations have to decide which links will be stronger and why. In the case of BEN, they have established their strongest links with non-minority environmental organizations and potential funding sources. Currently, they have weak links or none at all with other minority environmental organizations even though some of these have come into existence because of funding from BEN. If the organization is interested in articulating an alternative environmental agenda then it would be an advisable strategy to put more effort into developing links with the community and with other minority environmental organizations (Zimmer \& Aldrich, 1987; Granovetter, 1985; Light, 1972; Wilson \& Portes, 1980; Bonacich \& Modell, 1980; Wilson \& Martin, 1982; Fernandez \& McAdam, $1986)$. Their agenda is now driven by what pleases other mainstream 
environmental organizations and what will get funded. They have yet to build an agenda that has considerable input from the minority grassroots. The other minority environmental organizations have closer ties to minority communities; therefore, their chances of emerging with agendas that focus on the most immediate concerns of minority communities are greater.

There are resources in ethnic minority communities that are crucial to the survival of minority environmental groups. The community-based groups are using some of these resources well, but BEN isn't. Although the Black Environment Network leaders are quick to point out that the groups they serve are poor and don't have the money to pay membership fees, they are slow to recognize that there are other ways in which poor communities can contribute to causes and movement building. The civil rights and the environmental justice movements in the United States, and the numerous movements involving poor people all over the world demonstrate the existence of these resources. Even in Britain, the struggles of Blacks in Liverpool to be elected to office (Liverpool Black Caucus, 1986), demonstrate that there are vast resources in minority communities that can be tapped if the need arises. Ethnic minority environmental organizations have to recruit members to their organizations as paying or non-paying members. By establishing extensive links with existing social justice organizations they can use the bloc recruitment method $^{7}$ to gain access to large numbers of potential volunteers. Minority communities can provide the organization with other resources such as expertise in organizing demonstrations, campaigns, fundraising drives, to name a few (see Tilly, 1978; Jenkins, 1983; McCarthy \& Zald, 1977; 1973; and Zald \& McCarthy, 1979 for more detailed discussions of resource mobilization).

One should not be too quick to write off the possibility that a minority environmental organization could get some or most of its revenues from minority communities. Minorities have traditionally supported other community institutions like the church or labor unions that require members to pay tithes and dues. However, if minority environmental organizations want to get this level of monetary support from the community, they have to make their message relevant to the community. This means minority environmental organizations will have to work closely with members of the community to identify issues that will interest and help to mobilize people into action. In addition, it would be prudent to develop a skills data bank that would identify people who have special skills and expertise. This becomes quite useful on mobilization drives, and during research and teaching projects.

As things currently stand, there are no formal connections between minority environmental groups and labor; charitable status prohibits such ties. Minority organizations should devise creative ways of establishing connections 
with labor without jeopardizing their charity status. The Labour Party has already been working on a social and environmental justice platform that could be compatible with some of the issues a minority environmental organization might want to work on. Connections with the Labour Party would also give a small environmental organization a lot more political clout than it could muster on its own. If the charity status silences the organization too much, then the organization might consider if it can exist without it. Such a move can be contemplated only if the organization has tremendous community appeal and support.

Minority environmental organizations are well placed to start doing research that could be of interest to minority communities. Through such research efforts minority environmental organizations can start to engage other environmental organizations in more frank debates around the issues of diversity in the movement, the plight of the inner cities, exposures to environmental hazards, and access to open space. This kind of research could help to redefine the issues that concern those in the movement: it can broaden the focus of the movement and at the same time, and make it more responsive to issues that have significant impact on minority communities. Minority environmental groups should consider organizing regional and national workshops on issues relating to their survival, sphere of influence, and environmental justice issues. They should issue joint statements, organize joint efforts, and exchange ideas about strategizing. Most importantly they provide moral support and encouragement for each other.

Finally, groups have to decide what political style they will embrace and why. They will have to understand that an alternative agenda may contain radical ideas alien to most in the environmental movement. For these ideas to be taken seriously, they have to come from many voices and from many directions. In addition, it sometimes takes radical action to get these points across. It is, therefore, left to the groups to decide if this is a course of action they can embark on. It would be very difficult for the existing minority environmental groups to make profound changes by themselves right now because there are so few of them, and their actions are not coordinated. They have to form coalitions amongst themselves and with other groups to be effective. They have to choose coalition partners strategically. Alliances with other environmental groups can be a help or hindrance; they might get useful environmental help, but their efforts could be de-politicized. Other social justice organizations could help the groups to maintain a less conservative political position, but might not be able to provide the group with much-needed environmental expertise. It is clear that if minority environmental groups want to build an agenda in which minority concerns are central, they will have to re-evaluate their approaches and develop more extensive ties to minority communities. 


\section{ACKNOWLEDGMENTS}

This research was funded in part by the National Science Foundation. Special thanks to the faculty and staff of the Geography Department at the University of London for their help and support, and to the many environmental activists who graciously consented to be interviewed.

\section{ENDNOTES}

1. UK2000 is a consortium of voluntary organizations funded by the Department of the Environment. The partners are: Friends of the Earth, Royal Society for Nature Conservation, British Trust for Conservation Volunteers and Conservation Practice, Community Service Volunteers, Civic Trust, and the Groundwork Foundation.

2. For example, when a junior school headmaster contacted the Ramblers Association to complain that their publicity leaflets were so white-oriented that they would be highly unlikely to attract and interest any of his students who were mostly minorities, the Ramblers responded they would be happy to include the pictures of black members of their local groups if only they had any (Costner, 1991:1-2).

3. In 1991, a collaborative research project between a minority environmental group and a major environmental group was planned to explore minority exposures to pesticide residues.

4. With over 200 groups funded by the Black Environment Network to undertake environmental projects or countryside trips, several more new environmental groups may emerge as the environmental elements become a mote central part of the groups' agenda.

5. In this particular usage, the term black refers to people from African, Asian, Asian Indian heritage. As the BEN Report (1991f: 2) states: 'the use of the term 'black' in our name is used as a symbolic description of the common experience of all ethnic minority communities."

6. It should be noted that the organization does derive some power and is less marginal than other minority environmental organizations because of its close links with an established charity and with other established environmental organizations.

7. This involves the recruitment of blocs of people already affiliated with organizations and groups like churches and other community organizations. See Oberschall, 1973; Hicks, 1961; Lipset \& Wolin, 1965; Fernandez \& McAdam, 1986.

\section{REFERENCES}

Agyeman, J. (1988a). A pressing question for green organizations. Town and Country Planning, February. 50-51.

(1988b). Whose world is it? The Voice, September 6.

(1988c). Ethnic minorities - an environmental issue. Ecos 9(3).

(1989). Black people, white landscape. Town and Country Planning, December, 336-338.

(1990a). A positive image. Countryside Commission News, 45 (3), September/October.

(1990b). Ecological patchwork. PSLG, July/August, 22-24.

(1990c). Into the 1990's: Quality and equality. AREE Third Issue, 23-25.

(1990d). The right environment for aid. The Guardian, August 7.

Agyeman, J. \& Hare, T. (1988). Towards a cultural ecology. Urban Wildlife, June, 39-40. 
Aiken, M. \& Hage, J. (1968). Organizational interdependence and intra-organizational structure. American Sociological Review, 33, 912-930.

Aldrich, H. E. (1979), Organizations and Environments. Englewood Cliffs, New Jersey: Prentice-Hall.

(1972). An organization-environment perspective on cooperation and conflict between organizations in the manpower training system. In A. Negandhi (Ed.), Conflict and Power in Complex Organizations. Kent, Ohio: Center for Business and Economic Research, Kent State University.

Aldrich, H. E. \& Marsden, P. V. (1988). Environments and organizations. In Neil J. Smelser (Ed.), Handbook of Sociology. Beverly Hills: Sage.

Aldrich, H. E. \& Pfeffer, J. (1976). Environments of organizations. Annual Review of Sociology, 2, 79-105.

Allen, D. E.(1978). The Naturalist in Britain. Harmondsworth: Penguin.

Anwar, M. (1986). Race and Politics: Ethnic Minorities and the British Political System. London: Tavistock.

Asian Times (1990). The earth is yours too. December 11, 18-19.

Attenborough, C. (1991). Interview, UK2000 and Community Service Volunteers. June 28.

Ballard, R. (1983). Race and the census: What an ethnic question would show. New Saciety, May 12.

Benson, J. K. (1975). The interorganizational network as a political economy. Administrative Science Quarterly, 20, 229-249.

Bennett, A. \& Buchanan, S. (1988). Ethnic minorities and the environment report. November. Birnbaum, N. (1969). The Crisis of Industrial Society. London: Oxford University Press.

Black Environment Network (1990a). BEN/EMAS awards - 1990-1991. Bedford Square, London.

(1990b). What do I need to do a mural project? Bedford Square, London. (1990c). A little haven makes a lot of difference. Bedford Square, London. (1990d). Setting up a new BEN/EMAS Charity. Bedford Square, London, June 16. (1990e). Countryside trips - An evaluation of their significance for ethnic minority communities. Bedford Square, London, October.

(1991a). Black Environment Network projects 1991/92. Bedford Square, London. (1991b). Notes for the DoE meeting - May 1991. Bedford Square, London.

(1991c). Black Environment Network. Publicity Flyer. Bedford Square, London.

(1991d). A hundred butterfly children descend on Camley Street. Press release. Bedford Square, London.

(1991e). Notes to BEN projects. Bedford Square, London.

(1991f). The BEN Report. Bedford Square, London.

Blau, P. M. \& Scott, W. R. (1962). Formal Organizations. San Francisco: Chandler.

Blunden, J. \& Curry, N. (1985). The Changing Countryside. London: Croom and Helm.

Bonacich, E. \& Modell, J. (1980). The Economic Basis of Ethnic Solidarity. Berkeley: University of California Press.

Brown, E. (Reverend) \& Vernon, P. (1991). The Overstone Project report. Overstone Park, Northhampton, January.

Caribbean Ecology Forum (1988). Fight toxic imperialism: Support the campaign against waste dumping. Press release, London. (1989). Press release. January 26.

Caribbean Times (1988). US waste dump plans scrapped. December 1st. (1988). None are free, unless all are free. January 15. (1989). Waste protest continues. February 3.

Carson, R. (1962). Silent Spring. New York: Houghton Mifflin.

Cashmore, E. E. (1989). United Kingdom? Class, Race and Gender Since the War. London: Unwin \& Hyman.

Charity Commissioners for England and Wales (1990). Questionnaire for organizations intending to apply for registration under the Charities Act 1960. VI 2/90.

Community Education Network (1989). Black Environment Network. 9, \#11, November. (1989). A mural and a Muslim disabled association. 9, \#11, November. 
Cook, K. S. (1977). Exchange and power in networks of interorganizational relations. The Sociological Quarterly, 18, 62-82.

Correspondence to the Community Outreach Project Officer regarding the Lee Valley community celebration, April 1991.

Coster, G. (1991). Another country. Weekend Guardian, June 1-2, 4.

Daily Telegraph, Response to article (1991). Countryside must welcome Blacks. May 12.

DiMaggio, P. J. (1986). Structural analysis of organizational fields: A block model approach. Research in Organizational Behavior, 8, 335-370. (1983). State expansion and organizational fields. In R. H. Hall \& R. E. Quinn (Eds.) Organizational Theory and Public Policy. Beverly Hills: Sage Publications.

DiMaggio, P. J. \& Powell, W. W. (1983). The iron cage revisited: Institutional isomorphism and collective rationality in organizational fields. American Sociological Review, 48, 147-160.

Elsom, D. (1987). Atmospheric Pollution. Oxford: Blackwell.

Evan, W. M. (1966). An organizational-set: Toward a theory of interorganizational relations. In J. D. Thompson (Ed.), Approaches to Organizational Design. Pittsburgh: University of Pittsburgh Press.

Ethnic Minorities Awards Scheme (1990). It's your environment. Black Environment Network, Bedford Square, London.

(1990/91a). Opening up the environment. Black Environment Network, Bedford Square, London. (1990/91b). It's your environment. Black Environment Network, Bedford Square, London.

Fernandez, R. M. \& McAdam, D. (1986). Microstructural bases of recruitment to social movements. Paper presented to the 1986 American Sociological Association annual meetings.

Friends of the Earth, The Conference Planning Group (1988). Ethnic Minorities and the Environment Conference Report. Underwood Street, London.

Frisch, M. (1990). Directory for the Environment: Organizations, Campaigns and Initiatives. 3rd ed. London: Green Print.

Galaskiewicz, J. (1988). Mimetic and normative processes within an inter-organizational field: An empirical test. Unpublished manuscript.

(1985). Professional networks and the institutionalization of a single mind set. American Sociological Review, 50, 639-658.

Galaskiewicz, J. \& Burt, R, (1988). Interorganizational contagion in corporate philanthropy. Unpublished manuscript.

Galbraith, J. K. (1967). The New Industrial State. Boston: Houghton Mifflin.

Gilb, C. L. (1966). Hidden Hierarchies: The Professions and Government. New York: Harper and Row.

Granovetter, M. S. (1985). Economic action and social structure: The problem of embeddedness. American Journal of Sociology, 91, 481-510.

Grant, W. (1978). Insider Groups, Outsider Groups and Interest Group Strategies. University of Warwick, Department of Politics Working Paper \#19.

Green, B. (1981). Countryside Conservation. London: Allen \& Unwin.

Griffin, K. (1991a). Correspondence with Judy Ling Wong, Black Environment Network, January 28.

(1991b). Correspondence with Julian Agyeman, Black Environment Network, April 15. (1991c). Interview, July 1.

Guyana Human Rights Association Report (1988). Confessions.

Habermas, J. (1970). Toward a Rational Society: Student Protest, Science and Politics. Translated by J. Shapiro. Boston: Beacon Press.

Hannan, M. T. \& Freeman, J. (1977). The population ecology of organizations. American Journal of Sociology, 82 \#5, 929-964.

Hawley, A. H. (1968). Human ecology. In D. L. Sills (Ed.), International Encyclopedia of the Social Sciences. New York: Macmillan.

Hicks, J. D. (1961). The Populist Revolt. Lincoln, Nebraska: University of Nebraska Press.

Hilyard, N. (1981). Down in the dumps. Cover Up. London: New English Library. 
House of Commons (1988). Abbott attacks proposal for toxic waste dumping in Guyana. November 24.

Howton, F. W. (1969). Functionaries. Chicago: Quadrangle Books.

Interview (BEN) with Third World First, August 1990, Nel Druce - interviewer.

Jenkins, J. C. (1983). Resource mobilization theory and the study of social movements. Annual Review of Sociology, Vol. 9.

Johnson, S. (1973). The Politics of Environment: The British Experience. London: Tom Stacey.

Kimber, R., Richardson, J. J. \& Brookes, S. K. (1974). The Deposit of Poisonous Waste Act of 1972: A case of government by reaction. Public Law, Autumn.

Krishnarayan, V. (1990/91). Ethnic minorities - losing out on leisure. Community Network, Winter, p. 10.

(1991a). Ethical funding and the Black Environment Network. April 29. (1991b). Interview, Black Environment Network, June 17.

Lauman, E. O., Galaskiewicz, J. \& Marsden, P. V. (1978). Community structure as interorganizational linkages. Annual Review of Sociology, 4: 455-484.

Lefebvre, H. (1971). Everyday Life in the Modern World. Translated by S. Rabinovitch. New York: Harper.

Levine, S. \& White, P. E. (1961). Exchange as a conceptual framework for the study of interorganizational relationships. Administrative Science Quarterly, 5, 583-601.

Light, 1. (1972). Ethnic Enterprise in America. Berkeley: University of California Press.

Lipset, S. Martin \& Wolin, S. (1965). The Berkeley Student Revolt. New York: DoubledayAnchor.

Liverpool Black Caucus (1986). The Racial Politics of Militant in Liverpool: The Black Community's Struggle for Participation in Local Politics 1980-1986. Merseyside Area Profile Group and Runnymede Trust.

Local Action (1991a). Hindu temple group. British Trust for Conservation Volunteers, Oxfordshire, Spring.

(1991b). Opening up the environment: The Black Environment Network. British Trust for Conservation Volunteers, Oxfordshire, Spring.

Lowe, P. (1975). Science and the government: The case of pollution. Public Administration, Autumn.

(1983). Values and institutions in the history of British nature conservation. In A. Warren and F. Goldsmith (Eds.), Consenation in Perspective, Chichester: Wiley.

Lowe, P. \& Goyder, J. (1983). Environmental Groups in Politics. London: Allen \& Unwin.

Lowe, P., Clifford, J. \& Buchanan, S. (1980). The mass movement of the decade. Vole, January.

Marcuse, H. (1964). One Dimensional Man. Boston: Beacon Press.

Meyer, J. W. \& Rowan, B. (1977). Institutionalized organizations: Formal structure as myth and ceremony. American Joumal of Sociology, 83, 2, 340-363.

McCarthy, J. D. \& Zald, M. (1973). The Trend of Social Movements. Morristown, New Jersey: General Learning.

(1977). Resource mobilization and social movements. American Journal of Sociology, 82.

McCormick, J. (1989). The Global Environmental Movement. London: Belhaven Press. (1991). British Politics and the Environment. London: Earthscan Publications.

Memorandum of Association of Black Environment Network (1991). Application for charitable status, submitted to the charity commissioners, London.

Micklewright, S. (1987). Who are the new conservationists? Discussion Papers in Conservation \#46. University College, London.

Milson, S. (1991). On a rural ride to nowhere. Guardian, Letters, June 8.

Minutes \& agenda (1991a). Black Environment Network, Bedford Square, London, March 13. (1991b). Black Environment Network, Bedford Square, London, April 29 (1991c). Black Environment Network, Bedford Square, London, June 3. (1991d). Black Environment Network, Bedford Square, London, June 24. (1991e). Black Environment Network, Bedford Square, London, June 25.

Mizruchi, M. S. (1988). Similarity of political behavior among large American corporations. Unpublished manuscript. 
National Council for Voluntary Organizations (1988). What is a charity? Charity law and formation of charities. Bedford Square, London.

Guidance Note 2 (1981). Charities: Constitutional forms and liabilities of trustees. Bedford Square, London.

Oberschall, Anthony (1973). Social Conflict and Social Movements, Englewood Cliffs, New Jersey: Prentice-Hall.

OPCS and the Registrar General of Scotland (1983). Census 1981: Country of Birth, Great Britain. London: HMSO.

Perrow, C. (1986). Complex Organizations: A Critical Perspective. 3rd ed. New York: Random House.

Perry, A. H. (1981). Environmental Hazards in the British Isles. London: Allen \& Unwin.

Pfeffer, J. \& Salancik, G. (1978). The External Control of Organizations: A Resource Dependence Perspective. New York: Harper and Row.

Pollard, I. (1989). Pastoral interludes. Third Text, 7 (summer), 41-46.

Reed, A. L. Jr. (1986). Jesse Jackson Phenomenon: The Crisis of Purpose in Afro-American Politics. New Haven: Yale University Press.

Rex, J. \& Mason, D. (1986). Theories of Race and Ethnic Relations. Cambridge: Cambridge University Press.

Richardson, J. (1977). The environmental issue and the public. In Decision-Making in Britain, Block V (course material), Open University.

Scott, W. R. (1987). Organizations: Rational, Natural and Open Systems. 2nd ed. New York: Wiley.

Shirley, P. (1990). Report and evaluation of the work of the Birmingham and Black Country Ethnic Minority Awards Scheme Forum. Urban Wildlife Trust, May.

Shropshire Star (1990). People. June 25.

Smith, S. (1989). The Politics of 'Race' and Residence: Citizenship, Segregation and White Supremacy in Britain. Cambridge, England: Polity Press.

South London Press (1990). Young painters go green. July 27.

Talking Green (1991). Ashram Acres. February, 7.

Terreberry, S. (1968). The evolution of organizational environments. Administrative Science Quarterly, 12, 590-613.

Thomas, D. N. (1986). White Bolts, Black Locks. London: Allen \& Unwin.

Thomas, K. (1983). Man and the Natural World: Changing Attitudes in England 1500-1800. Harmondsworth: Penguin.

Thompson, J. D. (1967). Organizations in Action. New York: McGraw-Hill.

Thorley, Rev. B. (1988). Keynote address at the conference-Ethnic Minorities and the Environment, University of London, September.

Tilly, C. (1978). From Mobilization to Revolution. Reading, MA: Addison Wesley.

Times Chronicle Series (1990). Celebration of autumn. Bedford Square, London, October 18.

Times of London (1981). Tighter control sought in hazardous waste disposal. September 9: 4.

Touraine, A. (1971). The Post-Industrial Society. Translated by L. X. Mayhew. New York: Random House.

Turk, H. (1970). Interorganizational networks in urban society: Initial perspective and comparative research. American Sociological Review, 35, 1-19.

(1973b). Interorganizational Activation in Urban Communities. Washington, DC: American Sociological Association.

Townley, A. (1988). Ethnic minorities and the environment. Environment Now, December.

UK2000 (1991). UK2000 and BP - working together for all our tomorrows. Spring.

Urban Wildlife News (1990). Dances, flowers and murals. Pp. 14-15.

Vogel, D. (1986). National Styles of Regulation: Environmental Policy in Great Britain and the United States; Ithaca, NY: Cornell University Press.

The Voice (1989). Send the rubbish elsewhere. January 1.

Whetten, D. (1987). Interorganizational Relations. In J. Lorsch (Ed.), Handbook of Organizational Behavior. 
Wilson, K. \& Martin, W. A. (1982). Ethnic enclaves: A comparison of the Cuban and Black economies in Miami. American Journal of Sociology, 88, 135-60.

Wong, J. L (1991a). Notes on the Birmingham and Black Country Forum meeting. April 24. (1991b). Interview. Black Environment Network. June 11. (1991c). Correspondence with corporate sponsor. June.

Wrekin News (1990). Say it with flowers. Wrekin Council Newsletter, June 22.

Zald, M. \& McCarthy, J. D. (1979). The Dynamics of Social Movements: Resource Mobilization, Social Control, and Tactics. Cambridge, MA: Winthrop.

Zimmer, C. \& Aldrich, H. (1987). Resource mobilization through ethnic networks: Kinship and friendship ties of shopkeepers in England. Sociological Perspectives.

Zucker, L. G. (1983). Organizations as institutions. Research in the Sociology of Organizations, 2, $1-47$. 